\title{
Eleonora Sava \\ Images of Time \\ in the Romanian folk Chronotope
}

\begin{abstract}
This study proposes an analysis of the imagery of time in Romanian folklore, as it is outlined in a series of mythological narratives and beliefs recorded by ethnographers in the late nineteenth century and the first half of the twentieth century. The concept of chronotope is used as an analytical tool for understanding the imaginary universe of Romanian folklore. The analysed narratives encapsulate a set of ideas and representations regarding the social norms of the peasant communities in which the figures of weekly time - Saint Wednesday, Saint Friday, Marțolea (Tuesday-Evening), Joimărița (Thursday-Night), etc. - play a central role. Analysing these figures of time, the study reveals their function as guardians of compliance with traditional norms referring to conduct, work and food. The study also highlights the fact that chronotopes perform the role of cognitive schemes of the Romanian folklore imaginary. Keywords: Chronotope; Weekly Time; Romanian Folklore Imaginary; Mythological Narratives; Ethnology.
\end{abstract}

\section{ELEONORA SAVA}

Babeș-Bolyai University, Cluj-Napoca, Romania norasava@gmail.com

DOI: $10.24193 /$ cechinox.2020.38.19 $\triangle \mathrm{s}$ defined by Mikhail Bakhtin, the 1 chronotope is "the intrinsic connectedness of temporal and spatial relationships that are artistically expressed in literature." In his study on Forms of Time and of the Chronotope in the Novel, he proves that time and space are inseparable and that together they constitute a key pillar of literary creation. What the fusion of space and time means is that, in the text, time becomes the fourth dimension of space and space becomes a dimension of time. Time is spatial, in the sense that any movement or action in space is also a movement or action in time. In Bakhtin's terms, “Time, as it were, thickens, takes on flesh, becomes artistically visible; likewise, space becomes charged and responsive to the movements of time, plot and history. The intersection of axes and fusion of indicators characterises the artistic chronotope." Every imaginary universe has its own geography and temporality, the chronotope being "tantamount to the world construction that is at the base of every narrative text." ${ }^{3} \mathrm{As}$ Bakhtin insists, chronotopic structures form a gateway to the semantic sphere: "every entry into the sphere of meaning is accomplished only through the gates of the chronotope."4 
In folklore texts, chronotopes function as cognitive schemes of a fictional universe that reflects the traditional communities' system of ideas and representations and, implicitly, their worldview. Folklorists have revealed that the deep meaning of folklore narratives concerns the moral values and community norms of traditional societies. In this context, chronotopes offer a gateway to the social and moral norms that underlie the imagery of these narratives and that are the actual focus of the texts.

Starting from these theoretical insights, this study proposes an analysis of the images of time in Romanian folklore, taking into account the Bakhtinian idea that time represents the major dimension of the chronotope.

In the Romanian folklore imaginary, time has several defining features: "the popular-mythological understanding of time's fulness," an anthropomorphic vision, the relation with the sacred, heterogeneity, cyclicity, a laborious, collective and normative nature, and the involvement of moral and social values.

In his description of the folklore chronotope, Bakhtin insists on the popular-mythological understanding of time's fulness, based on the principle of "historical inversion": "The essence of this inversion is found in the fact that mythological and artistic thinking locates such categories as purpose, ideal, justice, perfection, the harmonious condition of man and society and the like in the past." The same is true of Romanian folk thinking, which projects the sacred order and harmony of the world into a time of origins, when God and the Holy Days of the week walked the earth. The particular manner in which this idea is transposed into Romanian folklore consists in granting anthropomorphic and sacred features to the days of the week, each of which is represented by a woman. The anthropomorphization of time is an integral part of the system of Romanian folk thinking, in which all the elements of the universe are imagined according to the human model.

The personified days are "holy" and belong to an otherworldly space. They live in the sky, in unknown places, in forests that man never sets foot in or in the netherworld: "Far away, where the sun rises, is the abode of Saint Monday and Saint Friday, where the sun sets live Saint Tuesday and Saint Wednesday, and where the sun is overhead is the home of Saint Thursday and Saint Sunday. And Saint Saturday lives by herself where the sun is completely hidden. [...] All [...] have a star in the sky and the star sits right above their dwelling. [...] And these seven stars bear the orbs of heaven and are called stars grandstars." The legend from which this passage is extracted contains a splendid image of the popular-mythological fulness of time, in which time, conceived as the seven stars (days of the week), supports the celestial vault and maintains the cosmic order. Equally, the stars of weekly time that "bear the orbs of heaven" clearly articulate a space-time continuum, structured on the principle of harmony.

In the Romanian folklore imaginary, time is characterised by heterogeneity, the days being differentiated into good and bad: "The days follow each their course, in their own way; one is better, the other is worse, but you need to take care of each one. There are days when everything runs like butter. Others, I don't know, they drain your energy, they dry you up."

Analysing the folklore chronotope, Bakhtin emphasised its laborious character, 
noting that time is measured by work-related events. ${ }^{9}$ This holds true in the case of traditional Romanian narratives referring to labour and food consumption. In these texts, the periods for labour and consumption are regulated for the entire community, having a collective and normative character. The time for work around the household is organised into days reserved for the household chores and days when certain activities are prohibited, while the restrictions for food of animal origin and plant origin are structured into days during which the consumption of meat is permitted and day when it is denied. Compliance with these rules is driven by the desire of the individuals to remain integrated in and valued by society, because "to stay integrated and to be part of the game is, perhaps, the very meaning of life as human life." ${ }^{10}$ Here is how a woman who was born at the end of the nineteenth century phrased this idea: "A man with sound judgment takes heed and care of everything if he wants to be happy and to be held in esteem by the world' [emphasis E.S.]. ${ }^{11}$ Thus, the engine of human actions is, ultimately, "the need to maintain a sense of belonging and to avoid exclusion from a particular reference group." ${ }^{12}$

In folklore texts, work-related rules are predicated on the specific characteristics of each entity that patronises the seven-day cycle of the week.

Monday is considered a day of good luck, favourable to man and his undertakings ${ }^{13}$ so it is good for starting any type of work. On a food prohibitions level, it is very often considered a fasting day, even though Christian dogma does not impose restrictions of this type.

Wednesday and Friday belong to the same category of beneficent time. Thus,
Wednesday is, like Monday, an auspicious day for lucrative activities, except for only two of the female activities: working with threads or yarns (spinning, weaving, sewing) and doing laundry. Friday is also generally propitious for work: "it's a good day to start any [work], ${ }^{14}$ but there are even tougher bans on female activities. Work that is restricted on Wednesdays is also prohibited on this day but, in addition, the preparation of food, especially bread, is not permitted. Also, Wednesdays and Fridays belong to the regime of food abstinence, given the prohibition to consume foods of animal origin.

Thursday activates its beneficial properties as regards both work: "it is a good day to start work on something" ${ }^{\prime 15}$ and marriage: "it is believed that only Sundays and Thursdays are good days for getting married; if someone gets married on other days, that marriage will not be a happy one." ${ }^{16}$

At the opposite pole are Tuesday and Saturday, deemed to be portentous days for starting new activities. "Tuesday's a bad day. It's not good for starting anything, and neither is Saturday"; "Saturday's not a good day, either for building a house, or for weaving something on a loom"; "Saturday's the day of the dead, not of the living. You can't build anything good; whatever you make doesn't last." ${ }^{17}$

The cyclicity of weekly time is evinced by the beliefs according to which Monday represents the beginning, the birth of time, while Saturday stands for the end, the death of time. In this sense, Saturday is, on the one hand, a day for commemoration of the departed and, on the other hand, a nefarious day for birth-giving: "Women pray to God that they don't deliver on Saturday, 
lest their babies should be born tired and feel exhausted throughout their life. You know, Saturday is the end of the week, that is, the end"; "If a woman gives birth on Saturday, they say the baby will die [...]. It will die, for it was born at the end of the week; you can't start with the end." 18

If the first six days of the week belong to a laborious chronotope, Sunday pertains to the chronotope of the feast. For peasant communities, the holiday is configured around a "core of holiness," which places it above mundane time, in an area that aspires to sacredness. ${ }^{19}$ Thus, Sunday evades the lucrative pace of $\mathrm{ev}^{-}$ eryday labour, any work being suspended now. Everything that happens during this day has a positive character: "weddings are held, bartering and other foundational gestures are made"20. Moreover, birth has a special meaning: "The woman who gives birth on a Sunday claims that her child will have good luck in life; everything will go smoothly for him and he will live a life of plenty. That's why women pray to give birth on Sundays." ${ }^{21}$

The Saints, who are personifications of the days of the week, serve as guardians of lucrative activities and food consumption: "All the days of the week are regarded as holy nuns." 22 The most important of these are Saint Sunday, Saint Friday and Saint Wednesday.

Saint Thursday is "first cousin to the sun"23; "the eldest sister of all the other holy days," "a great lady, who is worshipped by all the days of the week and from whom they receive orders, as to what they must do." ${ }^{24}$ The realm in which she lives is otherworldly: "she lives in the sky," or, according to other beliefs, "she lives across the World Ocean, in golden palaces. ${ }^{25}$ She has an ascetic behaviour, which distinguishes her from human beings: "she eats once every seven days, spending her time in prayers." 26 Her superhuman essence, as a "living goddess, ${ }^{\prime 27}$ is revealed in her miraculous powers: "she's a miracle worker." ${ }^{28}$ As such, she "does good to people"; "she appears to many people in their dreams to teach them what to do it in the case of sickness or loss. ${ }^{29}$ However, she suffers when they violate social work-and food-related norms: she is "bruised, wounded, made to bleed, slashed" ${ }^{30}$ because some of the people work on her day. It is not by chance that her wounds are caused by the symbols of the activities prohibited on this day: needles, spindles and distaffs turn from working tools into torture instruments when rules are not respected.

The same prestige is enjoyed by Saint Friday, who was worshipped on a weekly basis throughout the Balkan Peninsula. Many beliefs feature her as "the greatest of all days" 31 or as "sister to the other holy days, she being the oldest." ${ }^{32}$ She also belongs to an area of the sacred, of the otherworldly: she lives "at the gate of heaven," 33 "in a world untrodden by men," "in the netherworld" or "across nine countries and nine seas. ${ }^{\prime 4}$ She has a divine status: she is considered a "living goddess" 35 or a "saint." ${ }^{36}$ Endowed with miraculous powers, like Saint Sunday, she stands apart through her dual essence. If Sunday is by definition beneficent, the image of Saint Friday is antinomically constructed. Her benevolence is evident in her protective attitude: "she is the protectress of women"; ${ }^{37}$ "she comes to the aid of people in case of misfortunes." ${ }^{38}$ She is also well-meaning: "she helps people who travel"; "she defends them from dangers"; "she brings 
many good things to people. ${ }^{39}$ However, she is full of cruelty when work-related norms are violated: "if you work, she burns you or your children, spoils what you have worked, comes at night and punishes you." ${ }^{40}$ Her portraits reveal this antinomy, as her character sometimes appears in the form of an ancient woman, who is "said to be carrying 200 winters on her hump," ${ }^{41}$ while at other times she appears as a "goddess of beauty." ${ }^{2}$

The image of Saint Wednesday is depicted as complementary to Saint Friday, for she exhibits all the features of her elder sister. The personification of Wednesday is also considered "holy," since this is "a woman who has hallowed herself by her deeds." ${ }^{43}$ Her dwelling is "in heaven," "in the wastelands" or "in large palaces surrounded with a wall." ${ }^{44}$ She, too, is a "living goddess," having miraculous powers and an ambivalent nature. She is kind-hearted and benevolent: "people pray to her and give her alms"; "she helps travellers, shows herself to them in their dreams and advises them how to cure diseases," but she is both cruel and unforgiving when the rules about work are not observed: "if you work on her birthday, she comes at night and hurts you"; " if you spin or work on her birthday, she puts a curse on you." 45

The recurring phrase "living goddess," common to the three characters, captures the essence of their existential status in Romanian folklore imaginary. Although, as "goddesses," they are superhuman and sacred, they are, at the same time, "living," so they can appear in the space of humans, in order to protect, to reward or, on the contrary, to punish them. The type of action is determined by the diurnal or nocturnal moment of their visit to the worldly realm, since all their punitive and, as seen below, demonic interventions - occur through certain fractures in time, under the sign of the nocturnal register of the imaginary. Their description as dwellers of the otherworld underpins an imaginary of space that is dually structured into a world here and now and a world beyond. These worlds can communicate through certain cbronotopic rifts.

Beliefs about the Holy Days delineate a feminine universe, on the one hand, through the days that are personified as women, and on the other hand, through the recipients of their protective or vindictive actions, who are (almost) always women. The feminine components of the temporal imaginary derive from the essential role held by women in traditional societies, not only in creating and preserving traditions, but also in domestic work.

Also, the morphological and functional overlaps between the characters emphasize that Saint Friday and Saint Wednesday work as a pair, while Saint Wednesday, Saint Friday and Saint Sunday form a triad in the folklore imaginary.

The cult of these Saints - non-canonical, from a theological perspective - is a popular-mythological one. Romanian folklore conveys a vernacular religiosity, which consists of three interacting components: "official religion (what is accepted orthodoxy at any given time within institutional religion, although this changes with time and context), folk religion (meaning that which is generally accepted and transmitted belief and practice, regardless of the institutional view) and individual religion (the product of the received tradition - folk and official - and personal interpretations of this package, gained from experience 
and perceptions of efficacy)." ${ }^{46}$ If the Christian religion prohibits the consumption of foods of animal origin during the yearly and monthly fasts, "in the folk environment, this ascetic practice is translated into an additional prohibition honouring not only Saint Friday, but also a certain Saint Wednesday. The latter is absolutely unknown to the official hagiography and seems to have appeared as a duplicate of the former. The ban on culinary activities, especially bread-making, and on textile activities is justified by reference to these two figures, personifications of the two days of the week." ${ }^{47}$

The characters of Romanian vernacular religion show functional isomorphisms with the gods of Roman mythology, who perform precise tasks, being "so to speak, administrative gods who divided the different areas of human life among themselves." ${ }^{48}$ In the case of Romanian folklore, the patron Saints of the days of the week oversee the feminine sphere of culinary and textile activities. This isomorphism with the functional gods of Indo-European mythology is confirmed by their status as intercessors between humans and the supreme deity. They are "praying to God for the world"; "Time and time again, whenever God wants to punish the world, one or another of the six stars of the holy hags will appear, because, you know, the hags know what God is planning on doing and, kind-hearted as they are, they apprise the Christians." ${ }^{50}$

In the universe of fairy tales, the two pairs: Saint Friday/Saint Wednesday and Saint Friday/Saint Sunday are transformed, under the influence of a universal narrative structure, into triads of saints personifying the days of the week. Thus,
Saints Wednesday, Friday and Sunday are three sisters who live in other realms and perform the function of donor characters. In the folk versions of the fairy tale The Enchanted Pig (Husband, type 425 in the Aarne-Thompson-Uther Classification of Folk-Tales), they give the young woman embarking on a quest for her husband, who was enthralled by a witch, miraculous objects linked to the domestic space and household chores: a distaff, a spindle, a bundle and a loom that they work by themselves, a whorl that spins the yarn by itself, a table that lays itself, etc.

Another well-known folk tale puts the good girl and the bad girl in opposition (The Kind and the Unkind Girls, type 480 in the Aarne-Thompson-Uther Classification of Folk Tales). Here, Saint Friday is the distributor of rewards and punishments. She is visited by the good girl, who is rewarded for her hard work with a trunk full of bridal clothes, a distaff, a whorl and a loom. All of these things, which are made of gold and work by themselves, are necessary for the performance of female duties under the tutelage of Saint Friday and her doubles. Thus, "in Romanian fairy tales she appears as a donor and helper of the hero, playing an extremely important role in the economy of the story. Saint Friday, however, is not what one might call a general donor. In other words, she does not function as a helper to all kinds of heroes. Her appearance in the fairy tale is related to actions whose agents are women." ${ }^{51}$

An overview of these fairy tales can shed light on the chronotope of encounters with sacred beings. The time is always diurnal and the space, which is far away from the human world, is reached by the heroine after a very long and arduous journey. 
In The Enchanted Pig, she travels for three whole years, during which she wears out "three pairs of iron shoes and blunts three steel staffs," suggesting her entrance into another world and the initiatory nature of her journey. It is precisely this chronotope that determines the female character's encounter with Saint Friday and her sisters, in their benevolent aspect.

Having safely completed their initiation journeys, the heroines are now able to marry (the good girl is gifted a trunkful of bridal clothes) and to procreate (the girl in The Enchanted Pig carries a pregnancy for three years and cannot give birth until the end of her voyage, when she finds her husband). They receive from Saint Friday objects from the sphere of cooking and threadwork, because, in the traditional view, "the role of the married woman is to cook, do the domestic chores and give birth. At the same time, all these things involve an increase, an expansion, an almost alchemical transformation of matter." 52 Moreover, these texts clearly indicate Saint Friday's function within the folklore imaginary: to protect the "domestic matrimony" and married women, "both as wives and safekeepers of their conjugal ties, and as women in charge of the household affairs. ${ }^{153}$

In contrast to Saint Friday's image in the fairy-tale chronotope, in mythological narratives she is depicted as nocturnal and demonic. This hypostasis is also configured in relation to the female activities that are under the Saint's protection. Mythological stories are credited as real and have the value of exemplary narratives for the traditional communities, acting as warnings to those who deviate from the community norms.

Mythological texts about demoniacal appearances of the patron saints of weekly time rely on a unique narrative scheme, allowing us to consider them variants of one and the same story and, implicitly, to detect the characters' isomorphism. The narrative plot is as follows: on a Tuesday, a Thursday or a Friday, a woman gets down to work in the evening or even in the dead of night, despite the fact that work should only be performed during the daytime. She spins hemp or weaves, washes or boils the yarn she has spun/shirts. A stranger - an old hag, with a repulsive appearance - comes by the woman's house/courtyard. The hag intrudes into the protective space of the household, offering to help the woman, even though her intent is to hurt or slay her. The two work together (sometimes competing with one another). The woman goes to a neighbour/godmother, to borrow an object she needs for work: a cauldron, a vat, etc. Being older and, therefore, wiser, the neighbour/ godmother reveals to her that the visitor is not a human being, but, as the case may be, Tuesday-Evening (Marțolea), Saint Wednesday, Joimărița (Thursday-Night) or Saint Friday, and teaches her a ruse to drive the hag away. She should go home and shout that the place where the stranger lives is burning: the Mountains where Saint Friday dwells are burning, and so are the houses of Joimărița, the hills around the Canagali (Cana of Galilee) and the Mountains of Garaleu (a distorted version of Galilee, perhaps). While the woman is talking to the neighbour, the night visitor is preparing to punish her. She heats the oven to burn her, warms the water to scold her child, etc. Upon her return home, the woman does as the neighbour taught her. Since the children of Joimărița/Marțolea/ Saint Friday live there, the stranger rushes to save them. Meanwhile, the woman turns 
all the objects in the house upside down and locks the door. Realising that she has been fooled, the demonic being returns and calls out to all household utensils to open the door. They answer they cannot do that because they are upside down. A single object, which the woman left unturned, usually an oil lamp, goes to the door, but breaks on the way. The woman is saved by the crowing of roosters at dawn break, which marks the end of the time when demonic creatures can act.

Given that, in different versions, the mythological protagonist can be Saint Wednesday, Saint Friday, Tuesday Night (Marțolea), or Joimărița, it is clear that all of these characters act according to a single narrative programme and perform similar functions in the folklore imaginary. It is also obvious that the Saint Wednesday/ Saint Friday dyad is reduplicated as the pair Marțolea/Joimărița. Their intervention in the female universe of spinning, weaving and textile fulling reveals their function of overseers and patrons of the textile handicrafts in Romanian folk mythology.

The demonic nocturnal image of Saint Friday is antinomic to the diurnal one: she is "wicked and heinous," "an old hag," "such an ugly and hideous crone that she made you want to run away as far as possible, so you wouldn't have to lay eyes on her," "with one jaw in the sky and the other on the earth. ${ }^{\prime 54}$ This image overlaps with that of Joimărița: "an old woman, ugly as hell, with dishevelled hair and grinning teeth," ${ }^{55}$ "huge and bulky, tall as a tree and thick as a barrel," with "a mouth as wide as a pit, and teeth like spades." ${ }^{56}$ This is also similar to the somewhat more subdued image of Martolea, an old woman "with devilish power." ${ }^{57}$
Like the nightly instantiation of Saint Friday as Joimărița, the nocturnal personification of Wednesday as Marțolea can be explained by the fact that the traditional Romanian world relied for a long time on an ancient lunar-solar calendar, so the day started with the moon's ascent in the sky. In this regard, the ethnographer Tudor Pamfile stated the following at the beginning of the twentieth century: "And since the day begins, according to folk wisdom, on the evening of the previous day, at around the time the priest starts the service of vespers, Saint Friday comes by the housewives' homes on the evening of Thursday, just before Friday." ${ }^{\prime 58}$ Hence, she is sometimes referred to as Saint Friday and, at other times, as Joimărița.

The narrative scheme of these texts is built on the strict prohibition against women doing threadwork at a specific time: "on the evening of Tuesday, just before Wednesday," "on the evening of Thursday, just before Friday," "at night," "in the dead of night," "before the crowing of the roosters, because [evil beings] have no power after this time." ${ }^{59}$ Thus, demonic apparitions are products of the nocturnal chronotope. The transformation of these creatures from protectors into invaders of the domestic space is directly related to the folk vision on time as heterogeneous and discontinuous, with special attributes for the different moments of the day: "Morning is unlike evening and evening is unlike morning. [...] At night your soul is full of suspicion; those are evil hours." ${ }^{\prime 0}$ The heterogeneity of time (see above) is also found at the level of the hours of the day: "There are many hours in a day. Every hour is different from the next. When you want to do something or start work of any kind, you 
must pay attention to the time. Every hour has its own peculiar quality and its good or bad fortune is imprinted onto the place and the place acquires a different meaning [emphasis E. S.]." ${ }^{\prime 1}$ Thus, the auspicious or nefarious powers of time are transferred onto space and onto the beings that populate it. "Evil spirits" act from midnight to the crack of dawn, marked by an age-old natural timepiece, the crowing of roosters: "The dead of night comes after 12 o'clock. It is then that the evil spirits walk the earth until daybreak, when the roosters begin to crow, around three and a half in the morning. The dead of night is dark, it is the Archfiend." ${ }^{2}$ In other words, the irruption of the maleficent sacred is possible through the chronotopic rift created by the dead of night.

The house is configured as a protective and privileged space (it is the core of the traditional household and of family life; it is here that all the important events, from birth to death take place). It is a quintessentially feminine space, in the sense that it is the place of domestic activities, performed by women. In the traditional system of life, women had to do almost all the work in the household. This meant that they were much more connected to the house than men, who carried out their work mainly outdoors. Among these activities, textile handicrafts (hemp and wool processing, weaving, sewing, washing and fulling yarn/ clothes) and food preparation were essential. Spinning, in particular, was "the chief female occupation, the most honest, the holiest." ${ }^{63}$ The high degree of difficulty and complexity of this type of work, together with its crucial importance in the peasant household, which led it to be regarded as "holy work," generated a system of mythological representations of textile activities. Saint Friday enjoyed exceptional prestige in such representations, being depicted both as protectress of textile work and as the punisher of women who violated the norms related to this work. In the seventeenth century, for instance, Marcus Bandinus noted that "the Moldovans hold Saint Friday in higher esteem than God." ${ }^{64}$

Activities in this sphere are organised according to a certain work schedule and are carried out at a well-regulated pace: "there are certain days and periods when it is advisable or not to spin, in keeping with the local beliefs. [...] However, when there is work to be done, there should be no holding back. There can be no greater shame for a housewife than when she doesn't do her own retting or know how to work with hemp." ${ }^{65}$ Work should be done, as a rule, during the daytime; only the lazy do not finish their work in time and have to do their spinning at night. That is why women who work in the evening or at night will be punished. The patron saints of weekly time may be helpful in the diurnal chronotope, but in their nocturnal manifestations they chastise women who deviate from the community norms.

Thus, Tuesday-Evening (Marțolea), Joimărița and Saint Friday herself, in her demonic aspect, make their appearance in the homes of women who work with textiles (they spin hemp or weave, or wash shirts) that evening and cruelly punish them for working. Marțolea "strangles women who spin on Tuesday night or scald clothes with boiling water"; "she puts them in a vat and pours water on them"; "she roasted one in the oven because the woman had baked, and scalded another one with boiling water because she had boiled 
some garments." 66 Joimăriţa "throws the girls' distaffs and spindles into the fire, sets the unused whorls alight, burns or scorches their hands or fingers or nails by placing them on hot coals, cuts, chops, twists or crushes their nails with a hammer, scorches them with hemp torches, burns them with their whorls and everything else, sets fire to the whorls on top of their heads, on their eyes and hands, shoves their heads in the vat of tow and ignites them." 67

The mere enumeration of these exemplary punishments highlights the fact that any working tool can change its meaning according to the context. The oven, the cauldron, the vat, the needle, the spindle, the distaff, etc. are valuable and beneficial when used in the diurnal chronotope, in keeping with the norms that regulate the pace of weekly activities. However, their significance changes when these norms are violated, turning into genuine weapons in the nocturnal chronotope: they can burn, slay, injure, or cripple. A pattern structured on ambivalence emerges, therefore, depending on the chronotope: protagonists, activities and objects that are positively connoted during the daytime acquire negative, maleficent properties at night. Since the folklore chronotope is work-related (see above), these antinomic values support the idea of time being divided into segments reserved for work (during the day) and intervals devoted to rest (during the night). In customary societies, a balance can be struck between periods of work and rest.

In their demonic manifestations, Saint Friday, Joimărița and Marțolea borrow features of other terrifying beings from folk mythology: Muma Pădurii (Mother of the Forest), Zmei (Ogres), Vântoase (Strong
Winds), Iele (evil Fairies), Șoimane (Falcons), Strigoi (Ghouls), Caii lui Sântoader (Sântoader's Horses). All these characters aggressively invade the domestic universe and haunt the human beings solely in the nocturnal chronotope.

Thus, Joimărița "is a good sister of the Mother of the Forest"68, "an ogre-hag." 69 Tuesday-Evening or Marțolea behaves like the Vântoase: "Tuesday-Evening removed the door from the hinges, took the girl by the arm and began to spin her around, as if she were caught in the whirl of the Vântoase."70

Saint Friday punishes like the Ielel S,oimane, who are believed to turn those who hear their songs into sick, dumb, deaf, blind or lunatic individuals: "He who works on Friday will be maimed by Saint Friday and made into a misshapen, dumb, deaf or mad man"; "He who works [on Friday] will be "falconized" (se șoimănește),"71 that is, he will suffer a similar evil as that caused by the Soimane. Even though the aggression is the same, the setting of the action and the recipients are different: the Iele/S,oimane mutilate men outdoors, while Saint Friday has a protective or punitive role only in the feminine universe and indoors.

Saint Friday also has close relations with the world of the dead. Among the punishments for sinners who do not abide by the rules is a form of torture that places Saint Friday in the proximity of the strigoi (ghouls): "Then she [Saint Friday] went out and fetched one of them, buried not long before, with casket and all and hurled him into the hearth. When the roosters crowed, she vanished. The next day, the woman walked by the hearth and did not even glance at it, lest she should be frightened. She went to the village steward, people came and took 
the dead man away, and she was sick with fear for a long time." ${ }^{72}$

The ease with which Saint Friday moves from the protective space of the house to the dark recesses of death brings her closer to the strigoi, the undead, those travellers between worlds. The "vampiric and nocturnal" aspect ${ }^{73}$ of Saint Friday emerges here. Joimăriţa herself has an important funerary trait, as noted by the researchers of Romanian folk mythology. ${ }^{74}$ In fact, one of the ways to keep her at bay is to rub the doors with garlic, ${ }^{75}$ a means of defence deemed to be effective especially against the ghouls, but also against other nocturnal apparitions, such as Sântoader's Horses. The latter belong to the Centaurs' family, being pictured as overwhelmingly handsome young lads with equine features: they have hooves and a tail whose tip they hide in the top band of their boots. Like the nightly versions of Saint Friday and her doubles, their functions are related to time and female activities. Their role is to see whether spinning and other types of textile work are done according to the rules established by the community. The specific chronotope of their appearance is precisely delineated. They are active only one week of the year, namely the first week of Easter Lent, from Tuesday to Saturday. Textile work, such as spinning, warping or weaving, is prohibited in the evenings during this period. If they find young women working in a sewing bee, they come in and joke with them, invite them to dance and then punish them cruelly, or killing them. The most well-known story about Sântoader's Horses recounts that in a house or in a mill on the edge of a village, at a sewing bee, a bevy of girls is visited at night by some strangers, very handsome lads, who take them dancing. During the dance, one of the girls notices that the men have horsetails, gets scared and runs home. Her mother teaches her to rub all the pots with garlic and place them upside down, lest they should answer the request of Sântoader's Horses to open the door. She forgets to turn a single object, which starts moving towards the door, but breaks into pieces on the way. The girl is saved by the crowing of roosters. Her younger sister (who was too young to attend the sewing bee) and/or the rest of the girls left in the house/the mill on the outskirts of the village are "danced" by the Centaurs until they are killed.

Stories about Sântoader's Horses narrativize the rules of participation in a bee (age, behaviour and time) and the consequences of their violation. The fierce punishment of the younger child is due to her failure to comply with the age condition, since only "grown-up girls" could attend bees, at an age that was also deemed suitable for marriage. As the bee was a meeting place for young people, only girls who had reached puberty were allowed to interact with the lads, respecting thus certain canons of organization. In the stories about Sântoader's Horses, these canons are infringed and this leads to the punishment of the other girls. The Horses appear during Lent, a period of abstinence. In traditional societies, in addition to food prohibitions, restrictions of a sexual nature were imposed as well during Lent, including a ban on dancing. Within this temporal frame, "the episode of the dance marks a clear deviation from the rules of behaviour, which causes the bee to turn from a protective enclave into a space that is exposed to the most diverse dangers." 76

In some versions of this narrative, the mythological figures that show up at the 
bee in the dead of night are the ghouls, not Sântoader's Horses. ${ }^{77}$ This reinforces the idea that mythological characters are interchangeable and, by extension, that Sântoader's Horses have close connections with the underworld. "Those who barge in at the bee are the restless dead, erotically unfulfilled vagrants across the boundaries of life and death, who have returned to look for their loved ones in this world. Watchful for the women's slightest carelessness, they are eager to take them away for good, so as to ensure their peace in the nether world." 78

In all the narratives about encounters with demonic superhuman beings, human protagonists can keep the aggressors at bay. In the stories about the overseers of women's textile activities (Marțolea, Joimărița, Saint Friday or Sântoader's Horses), this can be achieved by turning the pots upside down, a powerful defensive rite, also present in the arsenal of the "battle against witchcraft." ${ }^{\prime 9}$ This recurring episode in narratives about encounters with superhuman beings reveals several essential aspects about the spatial imagination in folklore. All the demonic characters belong to the exterior space and have no power over humans, as long as they are kept beyond the boundaries of the household. The farther this exterior space is, the scarier it gets, since it is not mastered by man. Marțolea, Joimărița and Saint Friday come from an untrodden place (forests, the wilderness), an unknown land (the Mountains or the Hills of Garaleu or Canagali), or even from another realm. This may be, like in the case of ghouls, the realm of the dead. Thus, the emphasis is on the discontinuity of space, in parallel with the heterogeneity of time. As time is marked by a structural antinomy (auspicious/nefarious), space is imagined as qualitatively different (the protective interior/the dangerous or frightening exterior). The space mastered by humans reveals its protective qualities, while the one lying outside the area they control is likely to be populated by demonic beings.

However, even secure and beneficial spaces can become a site of demonic apparitions when people encroach upon social rules: Marțolea, Joimărița and Saint Friday enter the homes of women who work at night, while Sântoader's Horses or the ghouls arrive at a house where girls attend nocturnal bees. A space-time continuum is clearly delineated here, for any type of space, even the protective one, is likely to become contaminated by nocturnal maleficence.

The interchangeable nature of the protagonists is obvious in all these cases. Moreover, the morphological or functional isomorphisms of the characters, related to the migration of some narrative structures from one story to another, outline a "diffuse mythology." ${ }^{80}$ Although, at the texts' surface level, the representations of Romanian folk mythology "appear to form endlessly shifting sands" 81 , the depth level stores the traditional communities' ideas about workand conduct-related rules.

The discernible chronotopes in the Romanian folk texts configure a dually structured system of images: day time/ night time, auspicious/nefarious time, this world/the otherworld, protective topoi (house, farm, etc.)/perilous topoi (forests, the wilderness, etc.), in line with the mode of "contrastive thinking," 82 specific of folklore.

Nightly encounters with Saint Friday, Marțolea, Joimărița or Sântoader's Horses 
were not regarded as fictional by the members of traditional communities. They were seen as very personal experiences the villagers went through. Consequently, they were recounted and received as true events, which could not be questioned. The way in which these experiences were textualized, based on pre-existing narrative patterns, is essential: the chronotope played a central role in shaping these narratives. The value of the stories is not only literary. Above all, it resides in what the stories reveal about the traditional communities' outlook on the world. To contextualise and interpret them within this system of thought, I have correlated them with certain beliefs recorded by the Romanian ethnographers in the late nineteenth century and the first half of the twentieth century. These records can offer substantial information about the ways in which individuals represented the surrounding reality and their place within it in folklore. The analysis of these texts through the lens of a hermeneutics of the imaginary can shed light on the systemic nature of folklore images, organized by several principles, foremost among which are thinking in contrasts and the anthropomorphization of time. While thinking in contrasts determines the antinomic structure of time and space, as well as the ambivalence of mythological characters, the anthropomorphization of time generates the representation of temporal units according to the human model. What binds them together is the principle of order, which maintains the sacred harmony of the world. Superhuman beings - Saint Wednesday, Saint Friday, Marțolea, Joimărița, Sântoader's Horses are the keepers of this order. The anthropomorphized entities that express and govern time become the protagonists of narratives that condense the social norms related to behaviour, work and food, these norms representing, according to folklorists, the semantic core of mythological texts. The analysed texts reveal a feminine universe of weekly time. At the level of the imaginary, these coordinates capture the roles of women in peasant society, as repositories of tradition, defenders of domestic beliefs and rites, and main agents of household activities.

This study has been elaborated as part of the Project ROMIMAG (Enciclopedia Imaginariilor din România. Patrimoniu istoric și identități cultural-lingvisticel The Encyclopaedia of Imaginaries in Romania. Historical Patrimony and Cultural-Linguistic Identities) code PN-III-P1-1.2-PCCDI-2017-0326.

\section{Works Cited}

Bahtin, Mihail, Formele timpului și ale cronotopului în roman. Eseuri de poetică istorică, în Mihail Bahtin, Probleme de literatură şi estetică. Translated by N. Iliescu. Foreword by Marian Vasile, Bucureşti, Univers, 1982, p. 295-490.

Bemong, Nele, Borghart, Pieter, "Bakhtin's Theory of the Literary Chronotope: Reflections, Applications, Perspectives," in Bemong, Nele, Borghart, Pieter \& alii (Eds.), Bakbtin's Theory of the Literary Chronotope: Reflections, Applications, Perspectives, Gent, Academia Press, 2010, p. 3-16.

Bernea, Ernest, Cadre ale gândirii populare românești.Contribuții la reprezentarea spațiului, timpului și cauzalității, București, Cartea românească, 1985.

Bîrlea, Ovidiu, Folclorul românesc, vol. I, București, Minerva, 1981. 
Bowman, Marion, "Vernacular Religion, Contemporary Spirituality and Emergent Identities. Lessons from Lauri Honko," in Approaching Religion, No.1, 2014, p. 101-113.

Brill, Tony, Legendele românilor, vol. I, Legendele cosmosului, București, Editura Grai și Suflet - Cultura Națională, 1994.

Cassirer, Ernst, Eseu despre om. O introducere in flozofia culturii umane, Translated by Constantin Coșman, București, Humanitas, 1994.

Fabre-Vassas, Claudine, "Paraschiva-Vendredi. La sainte des femmes, des travaux, des jours," in Terrain, No. 24, 1995, p. 57-74.

Fochi, Adrian, Datini și eresuri populare de la sfarsșitul secolului al XIX-lea. Răspunsurile la chestionarele lui N. Densusianu, București, Minerva, 1976.

Gorovei, Artur, Credinți și superstiții ale poporului român, București, Editura Grai și Suflet - Cultura Națională, 1995.

Hedeșan, Otilia, Pentru o mitologie difuză, Timișoara, Marineasa, 2000.

Hedeșan, Otilia, Basme din Banat, Timișoara, Editura Universităţii de Vest, 2016.

Mesnil, Marianne, “Demonășsi creștină: Sfânta Vineri,"in Marianne Mesnil, Assia Popova, Etnologul, intre șarpe și balaur. Eseuri de mitologie balcanică, Translated by Ioana Bot and Ana Mihăilescu, București, Paideia, 1997, p. 363-392.

Mihăilescu, Vintilă, "Dificila deconstrucție a sarmalei. Discurs despre tradiție," in Cristina Papa, Giovanni Pizza, Filippo M. Zerilli (Eds.), Cercetarea antropologică în România. Perspective istorice și etnografice, Cluj-Napoca, Clusium, 2004, p. 181-206.

Mușlea, Ion - Bîrlea, Ovidiu, Tipologia folclorului din răspunsurile la chestionarele lui B. P. Hasdeu, București, Minerva, 1970.

Mușlea, Ion, “O ființă demonică românească: Joimărița,"in Ion Mușlea, Cercetări etnografice și de folclor, București, Minerva, 1972, p. 223-237.

Nicolau, Irina, Ghidul sărbătorilor românești, București, Humanitas, 1998.

Niculiță-Voronca, Elena, Datinile și credințele poporului român adunate și așezate în ordine mitologică, Iași, Polirom, vol. I-II, 1998 [1903].

Pamfile, Tudor, Industria casnică la români. Trecutul și starea ei de astăzi, București, Leipzig, Viena, Socec \& Comp, 1910.

Pamfile, Tudor, Mitologie românească, București, All, 1997 [1916].

Taloș, Ion, Gândirea magico-religioasă la români. Dicționar, București, Editura Enciclopedică, 2001.

\section{Notes}

1. Mihail Bahtin, Formele timpului și ale cronotopului în roman. Eseuri de poetică istorică, in Mihail Bahtin, Probleme de literatură şi estetică. Translated by N. Iliescu. Foreword by Marian Vasile, Bucureşti, Univers, 1982, p. 294.

2. Ibid., p. 295.

3. Nele Bemong, Pieter Borghart, "Bakhtin's Theory of the Literary Chronotope: Reflections, Applications, Perspectives," in Bemong, Nele, Borghart, Pieter \& alii (Eds.), Bakbtin's Theory of the Literary Chronotope: Reflections, Applications, Perspectives, Gent, Academia Press, 2010, p. 3.

4. Bahtin, Formele timpului și ale cronotopului .., p. 490.

5. Bahtin, Formele timpului și ale cronotopului ..., p. 365.

6. Ibidem, 365-366.

7. Tony Brill, Legendele românilor, vol. I, Legendele cosmosului, București, Editura Grai și Suflet - Cultura Națională, 1994, p. 219.

8. Ernest Bernea, Cadre ale gândirii populare românești. Contribuții la reprezentarea spațiului, timpului și cauzalității, București, Cartea românească, 1985, p. 187.

9. Bahtin, Formele timpului și ale cronotopului..., p. 435. 
10. Vintilă Mihăilescu, "Dificila deconstrucție a sarmalei. Discurs despre tradiție," în Cristina Papa, Giovanni Pizza, Filippo M. Zerilli (Eds.), Cercetarea antropologică în România. Perspective istorice și etnografice, Cluj-Napoca, Clusium, 2004, p. 186.

11. Bernea, Cadre ale gândirii populare românești..., p. 175.

12. Mihăilescu, Dificila deconstructie...., p. 186.

13. Adrian Fochi, Datini și eresuri populare de la sfârșitul secolului al XIX-lea. Răspunsurile la chestionarele lui N. Densusianu, București, Minerva, 1976, p. 362; Ion Mușlea, Ovidiu Bîrlea, Tipologia folclorului din răspunsurile la chestionarele lui B. P. Hasdeu, București, Minerva, 1970, p. 413.

14. Mușlea-Bîrlea, Tipologia folclorului ...., p. 418.

15. Ibid., p. 417.

16. Gorovei, Artur, Credinți și superstiții ale poporului român, București, Editura Grai și Suflet - Cultura Națională, 1995, p. 112.

17. Bernea, Cadre ale gândirii populare românești..., p. 188.

18. Ibid.

19. Irina Nicolau, Ghidul sărbătorilor românești, București, Humanitas, 1998, p. 13.

20. Bernea, Cadre ale gândirii populare românești..., p. 190.

21. Ibid., p. 191.

22. Mușlea-Bîrlea, Tipologia folclorului..., p. 219.

23. Elena Niculiță-Voronca, Datinile și credințele poporului român adunate și așezate în ordine mitologică, Iași, Polirom, vol. I, 1998 [1903], p. 220.

24. Mușlea-Bîrlea, Tipologia folclorului ..., p. 219.

25. Ibid.

26. Ibid.

27. Ibid.

28. Ibid.

29. Ibid.

30. Ibid.

31. Elena Niculiță-Voronca, Datinile și credințtele ...., I, p. 227.

32. Mușlea-Bîrlea, Tipologia folclorului ..., p. 222).

33. Fochi, Datini și eresuri ...., p. 277.

34. Fochi, Datini şi eresuri ...., p. 277.

35. Mușlea-Bîrlea, Tipologia folclorului ..., p. 221-222.

36. Fochi, Datini si eresuri ...., p. 276.

37. Ibid.

38. Ibid., p. 277.

39. Ibid.

40. Mușlea-Bîrlea, Tipologia folclorului ..., p 222.

41. Ion Taloș, Gândirea magico-religioasă la români. Dicționar, București, Editura Enciclopedică, 2001, p. 156.

42. Fochi, Datini și eresuri ....,p. 276.

43. Mușlea-Bîrlea, Tipologia folclorului ..., p. 220.

44. Ibid.

45. Ibid., p. 222.

46. Marion Bowman, "Vernacular Religion, Contemporary Spirituality and Emergent Identities. Lessons from Lauri Honko," in Approaching Religion, No.1, 2014, p. 102.

47. Marianne Mesnil, "Demonă și creștină: Sfânta Vineri," in Marianne Mesnil, Assia Popova, Etnologul, intre șarpe și balaur. Eseuri de mitologie balcanică, Translated by Ioana Bot and Ana Mihăilescu, București, Paideia, 1997, p. 375.

48. Ernst Cassirer, Eseu despre om. O introducere in filozofia culturii umane, Translated by Constantin Coșman, București, Humanitas, 1994, 138. 
49. Mușlea-Bîrlea, Tipologia folclorului ..., p. 222.

50. Brill, Legendele românilor ..., p. 219.

51. Otilia Hedeșan, Pentru o mitologie difuză, Timișoara, Marineasa, 2000, p. 99.

52. Otilia Hedeșan, Basme din Banat, Timișoara, Editura Universității de Vest, 2016, p. 90.

53. Mesnil, “'Demonăși creștină ...," p. 373.

54. Tudor Pamfile, Mitologie românească, București, All, 1997 [1916], p. 108-111.

55. Ibid., p. 97

56. Mușlea-Bîrlea, Tipologia folclorului ..., p. 201.

57. Fochi, Datini și eresuri ....,p. 196.

58. Pamfile, Mitologie românească ..., p. 108.

59. Ibid., pp. 100-112.

60. Bernea, Cadre ale gândirii populare românești ..., p. 191.

61. Ibid., p. 193.

62. Ibid.

63. Tudor Pamfile, Industria casnică la români. Trecutul și starea ei de astăzi, București, Leipzig, Viena, Socec \& Comp, 1910, p. 209.

64. Hedeșan, Pentru o mitologie difuză ..., p. 96.

65. Pamfile, Industria casnică..., p. 209.

66. Fochi, Datini și eresuri ....,p. 197.

67. Ibid., 202-203.

68. Pamfile, Mitologie românească ..., p. 98.

69. Fochi, Datini și eresuri ....,p. 183.

70. Pamfile, Mitologie românească ..., p. 105.

71. Fochi, Datini și eresuri ....,p. 279.

72. Niculiță-Voronca, Datinile și credințele ...., 1998, I, p. 230; Pamfile, Mitologie românească ..., p. 110.

73. Mesnil, “Demonăși creștină ...," p. 379.

74. Ion Mușlea, “O ființă demonică românească: Joimărița," in Ion Mușlea, Cercetări etnografice și de folclor, București, Minerva, 1972, p. 226; Hedeșan, Pentru o mitologie difuză ..., p. 101.

75. Pamfile, Mitologie românească ..., p. 97.

76. Hedeșan, Pentru o mitologie difuză..., p. 118.

77. Mușlea-Bîrlea, Tipologia folclorului ..., p. 256, 269.

78. Hedeșan, Pentru o mitologie difuză..., p. 119.

79. Claudine Fabre-Vassas, "Paraschiva-Vendredi. La sainte des femmes, des travaux, des jours," in Terrain, No. 24, 1995, p. 66.

80. Hedeșan, Pentru o mitologie difuză..., p. 13.

81. Ibid.

82. Ovidiu Bîrlea, Folclorul românesc, vol. I, București, Minerva,1981, p. 47. 